\title{
Anti-oxidative and proteolytic activities and protein profile of laticifer cells of Cryptostegia grandiflora, Plumeria rubra and Euphorbia tirucalli
}

\author{
Cleverson D. T. de Freitas ${ }^{1 *}$, Diego P. de Souza ${ }^{2}$, Eliane S. Araújo² ${ }^{2}$ Mariana G. Cavalheiro², \\ Luciana S. Oliveira² and Márcio V. Ramos² .
}
${ }^{1}$ Departamento de Biologia, Universidade Federal do Piauí, Campus Floriano, BR 343, Km 3,5, Bairro Melladão, CEP 64800-000, Brasil.
${ }^{2}$ Departamento de Bioquímica e Biologia Molecular, Universidade Federal do Ceará, Campus do Pici, Cx. Postal 6033, Fortaleza, Ceará. CEP 60451-970, Brasil.
* Corresponding authors: Cleverson D.T. Freitas (cleversondiniz@hotmail.com) and Márcio V. Ramos (vramos@ufc.br). Phone: +55 8533669403 Fax: +55 8533669789
Received: 05 January 2010; Accepted: 05 April 2010.

\begin{abstract}
In this study, proteins extracted from laticifer cells of three plants were examined by electrophoresis, mass spectrometry (MALDITOF) and characterized in respect of proteolytic, chitinolytic and anti-oxidative activities by means of zymography and colorimetric assays. Acidic proteins with molecular masses between 12.5 and $74.5 \mathrm{kDa}$ predominated in laticifers of $P$. rubra. This profile was not found in laticifers of $C$. grandiflora and $E$. tirucalli. The later was poor in respect of proteins. Strong anti-oxidative activity of superoxide dismutase (E.C. 1.15.1.1) was detected in P. rubra and C. grandiflora latices, and to a lesser extent ascorbate peroxidase (E.C. 1.11.1.1) and isoforms of peroxidase were seen. Catalase (E.C. 1.11.1.6) was detected only in laticifer cells of $C$. grandiflora. Chitinase (E.C. 3.2.1.14) was the sole activity found in laticifer cells of $E$. tirucalli, but was also detected in the other latices. The strong proteolytic activity of $C$. grandiflora was shown to be shared by at least three distinct cysteine proteinases (E.C. 3.4.22.16). Serine, aspartic and metaloproteinases were not detected. In laticifer cells of $P$. rubra, four proteinases were detected, including cysteine and serine types. This study reports new protein data of laticifers from plants that have been poorly investigated in this respect and contributes to the understanding of biochemical and functional aspects of laticifers in plants.
\end{abstract}

Key words: catalase, chitinase, cysteine proteinase, latex, peroxidase.

Abbreviations: CgLP, Cryptostegia grandiflora Laticifer Proteins; CpLP, Calotropis procera Laticifer Proteins; DTT, Dithiothreitol; PEP, pepstatin; PrLP, Plumeria rubra Laticifer Proteins; EtLP Euphorbia tirucalli Laticifer Proteins.

\section{INTRODUCTION}

Latex is a biological fluid common in plants. Nearly $6 \%$ of all vascular plant species are recognized as constructing laticifers. These structures form pressurized canal systems from which latex is produced, accumulated and commonly exudes upon tissue damage. There has been a growing interest in laticifers and their own metabolism, and although there is still limited information available, the importance of these plant fluids has been increasingly recognized and revised (Hagel et al., 2008; Pickard, 2008). Nonetheless, few latexproducing plants have been studied in detail and many laticifer 
plants involved in toxic events or exhibiting pharmacological properties still deserve basic biological investigations. Almost all literature available concerning biochemical, functional or toxic aspects of laticifer contents is devoted to the latex of the rubber tree (Hevea brasiliensis) because its latex is used worldwide as a source of natural rubber (cis-poliisoprene) which is manufactured (Cornish, 2001). Latex is a fluid, frequently with a milky aspect, synthesized by specialized cells called laticifers. Laticifers may be classified according to their ultra structural genesis as articulated and non-articulated (Kekwick, 2001). The main difference is that the cell walls of articulated laticifers, which form a unique row of adjacent cells, are intact or partially perforated, while non-articulated laticifers arise as a unique cell which elongates indefinitely forming its own canal system (Hagel et al., 2008). Such particularity seems to determine the intensity and speed at which latex exudates following injury. This characteristic sometimes limits latex collecting for further laboratory study. This may explain the lack of information and limited biochemical studies of many latices.

The biological significance of latex in plants is still poorly understood. In the light of accumulated published data, most authors hold the hypothesis of a defensive role of latices towards insects and phytopathogens. This belief is mainly supported by the phytochemical profile found in distinct latices (Konno et al., 2004; Taira et al. 2005; Farias et al., 2007). It is not only of physiological importance but also of botanic interest to understand the metabolic activities of latices and their implications in plant protection. Recent studies of latices have contributed to the understanding of the occurrence and structure of secondary metabolites naturally accumulated in laticifers (Elsasser et al., 2005; Mazoir et al., 2008). However, studies committed to protein activities in latices under a physiological perspective have only just begun. We have played special attention to the protein profile of different laticifers and attempted to establish some aspects of their biochemical profile. Recently, we reported the overall protein and enzymatic activities in the latex of the shrub Calotropis procera which have been further proved to be implicated in the detrimental effect on insects (Freitas et al., 2007; Ramos et al., 2007). Here we extend this approach to give new insights into the protein activity of three new latices which have been poorly investigated.

\section{MATERIALS AND METHODS}

Chemicals: $\quad$ N-Benzoyl-DL-argininyl-p-nitroanilide (BapNA), N-benzoyl- DL-arginine b-naphthylamide hydrochloride (BANA), transepoxysuccinyl-L-leucylamido (4-guanidio)-butane (E-64), ethylenediaminetetraacetic acid (EDTA), phenylmethylsulphonylfluoride (PMSF), 4-(dimethylamino)cinnamaldehyde, pepstatin (PEP), azocasein, glycolchitin, calcoflur MR 28 were purchased from Sigma Chemical Co. (St. Louis, M0). Immobiline DryStrips pH 3-10 (11 cm), urea, thiourea, [3-(3-Cholamidopropyl)-dimethylammonio]1-propane sulfonate (CHAPS), IpG-buffer, Dithiothreitol (DTT), lodoacetamide (IAA), glycerol and molecular weight markers were from GE HealthCare, Brazil. Others chemicals were of analytical grade.

Plant material: Health plants of Cryptostegia grandiflora R.Br. (Apocynaceae), Plumeria rubra L. (Apocynaceae) and Euphorbia tirucalli L. (Euphorbiaceae) growing in the vicinities of Fortaleza, state of Ceará, Brazil, were used as the source of fresh latex. Each plant material was identified by a botanist and the vouchers N. 040409 (C. grandiflora), N. 15018 (P. rubra) and N. 38702 (E. tirucalli) were deposited at the Prisco Bezerra Herbarium of the Universidade Federal do Ceará, Brazil.

Latex processing: The latices of $C$. grandiflora, $P$. rubra and $E$. tirucalli were collected by cutting ends of branches and left to flow off in distilled water to obtain a 1:1 (v/v) ratio. The mixtures were gently agitated during collection to overcome the tendency of a coagulation-like effect of the materials. The samples were centrifuged at $5,000 \mathrm{~g}$ for $10 \mathrm{~min}$ at $4^{\circ} \mathrm{C}$. The rubber-like precipitates arisen after centrifugation were separated and the supernatants were exhaustively dialyzed against distilled water using membranes of 8,000 molecular mass cut-off. Each material was maintained at $8^{\circ} \mathrm{C}$ for $60 \mathrm{~h}$ and dialysis water renewed three times daily. The retained materials were centrifuged again in the conditions described above. The precipitated materials were joined to the previous ones and freeze dried. The clean, rubber-free supernatants which yielded almost all soluble proteins were freeze dried separately. These protein fractions were named laticifer proteins (LP) and nominated as follows: CgLP, PrLP and EtLP corresponding to $C$. grandiflora, $P$. rubra and $E$. tirucalli, respectively. These materials were used in further experiments performed for enzymatic analysis. Samples intended to be used in electrophoresis were collected in distilled water 
containing $10 \mathrm{mM}$ IAA and $5 \mathrm{mM}$ PMSF to avoid endogenous proteolysis. Protein content in the samples was measured according to the Bradford's method with bovine serum albumin as the protein standard (Bradford, 1976). The laticifer proteins from Calotropis procera (CpLP) whose biochemical studies were already described were used as reference in some assays.

Mass spectrometry: Spectra of the molecular masses of major proteins of $\mathrm{CgLP}$, PrLP and EtLP were performed by Matrix Assisted Laser Desorption lonization (MALDI) and Time of Fly (TOF) analysis using an ABI 4700 Proteomics Analyzer (Applied Biosystems). Sinapinic acid was used as the matrix in all cases.

Polyacrylamide gels electrophoresis in the presence of SDS (SDS-PAGE): SDS-PAGE was performed as previously described (Laemmli, 1970), with some modifications. Protein samples were dissolved in sample buffer [0.0625 M Tris- $\mathrm{HCl}$ buffer ( $\mathrm{pH} \mathrm{6.8)} \mathrm{containing} \mathrm{1 \%} \mathrm{SDS].} \mathrm{Runs} \mathrm{were} \mathrm{performed}$ at $25 \mathrm{~mA}$ per gel at $25^{\circ} \mathrm{C}$ for $2 \mathrm{~h}$. The gels were stained with Coomassie Brilliant Blue (R-250) solution in water: acetic acid: methanol (5/1/4, v/v/v) and de-colored with the same solution without the dye.

Two-dimensional polyacrylamide gel electrophoresis (2-DE): Immobiline DryStrips, pH 3-10 (11 cm) were rehydrated overnight with $[7 \mathrm{M}$ urea/2 $\mathrm{M}$ thiourea/1\% CHAPS/2\% appropriate IpG-buffer/bromophenol blue] solution containing the proteins. The proteins were dissolved with extraction buffer (50 mM Pyridine, $10 \mathrm{mM}$ thiourea, $1 \%$ SDS, pH 5.0) as previously described (Vasconcelos et al., 2005). The electrophoretic runs were performed on an Ettan IPGphor II system (Amersham Pharmacia Biotech). Electrical conditions were as suggested by the supplier. After the first-dimensional run, the IpG gel strips were incubated at $25^{\circ} \mathrm{C}$ in $3 \mathrm{~mL}$ of equilibration buffer (50 mM Tris- $\mathrm{HCl}, 30 \%$ Glycerol, $6 \mathrm{M}$ urea, 2\% SDS and traces of bromophenol blue) containing $30 \mathrm{mg}$ of DTT for $20 \mathrm{~min}$ and in $3 \mathrm{~mL}$ of equilibration buffer containing $75 \mathrm{mg}$ of iodoacetamide for 20 min. The second dimension electrophoreses were performed on a vertical system with uniform $12.5 \%$ separating gel (14 $x 14 \mathrm{~cm}$ ), at $8^{\circ} \mathrm{C}$. Protein spots in 2-DE gels were labeled by Coomassie Brilliant Blue (R-250) solution. Each experiment was conducted in duplicate. The gels were scanned using an Imager Scanner (Amersham Biosciences) with the help of LabScan ${ }^{\circledR}$ software. All details of individual gels and comparative analysis were performed using ImageMaster 2D Platinum ${ }^{\circledR}$ Software (Amersham Biosciences).

Colorimetric assays and zymograms: Anti-oxidative activities (SOD, CAT and APX): Samples of CgLP, PrLP and EtLP (10 $\mathrm{mg} \mathrm{mL}^{-1}$ ) are processed separately and the assays were carrying out in parallel. Each sample was dissolved in $50 \mathrm{mM}$ potassium phosphate buffer ( $\mathrm{pH} 7.0$ ) containing 0.1 mM EDTA. The mixtures were centrifuged at $12,000 \mathrm{~g}$ for 15 $\min$ at $4^{\circ} \mathrm{C}$. The soluble phases were used in all anti-oxidative enzyme activity assays. The measurements were determined in duplicate and the results were expressed as a mean value \pm SD (Standard Deviation).

Total superoxide dismutase (SOD, E.C. 1.15.1.1) activity was determined by measuring its ability to inhibit the photochemical reduction of nitroblue tetrazolium chloride (NBT), as described (Giannopolitis et al., 1977). The reaction mixture $(1.5 \mathrm{~mL})$ contained $50 \mathrm{mM}$ phosphate buffer $(\mathrm{pH}$ 7.0), $0.1 \mathrm{mM}$ EDTA, $13 \mathrm{mM}$ methionine, $75 \mathrm{mM} \mathrm{NBT}, 2 \mathrm{mM}$ riboflavin and CgLP or PrLP or EtLP. Riboflavin was added last and the tubes were shaken and illuminated under two 20 W fluorescent lamps. The reaction was left for $15 \mathrm{~min}$, after which the lights were switched off and the tubes covered with a black cloth. The absorbance of the reaction mixture was measured at $560 \mathrm{~nm}$. One unit of SOD activity (U) was defined as the amount of enzyme required to cause a $50 \%$ reduction in the NBT photoreduction rate. The results were expressed as $\mathrm{U} \mathrm{g}^{-1}$ of dry mass (DM).

Total catalase (CAT, E.C. 1.11.1.6) activity was measured as described (Beers and Sizer, 1952). The reaction mixture $(1.5 \mathrm{~mL})$ consisted of $50 \mathrm{mM}$ phosphate buffer ( $\mathrm{pH} 7.0), 0.1$ mM EDTA, $20 \mathrm{mM} \mathrm{H}_{2} \mathrm{O}_{2}$ and samples of CgLP or PrLP or EtLP. The reaction was started by adding the enzyme extract, and the decrease in $\mathrm{H}_{2} \mathrm{O}_{2}$ was monitored at $240 \mathrm{~nm}$ and quantified by its molar extinction coefficient $\left(36 \mathrm{M}^{-1} \mathrm{~cm}^{-1}\right)$. The results were expressed as $\mu \mathrm{Mol} \mathrm{H}_{2} \mathrm{O}_{2}$ min $^{-1} \mathrm{~g}^{-1} \mathrm{DM}$.

Total peroxidase activity (APX, E.C. 1.11.1.1) was performed by two methods. Colorimetric assays were performed according to (Nakano and Asada, 1981). The reaction mixture $(1.5 \mathrm{~mL})$ composed of $50 \mathrm{mM}$ phosphate buffer (pH 7.0), $0.1 \mathrm{mM}$ EDTA, $0.5 \mathrm{mM}$ ascorbate, $1.0 \mathrm{mM}$ $\mathrm{H}_{2} \mathrm{O}_{2}$ and samples of $\mathrm{CgLP}$ or PrLP or EtLP. The reaction was started by adding $\mathrm{H}_{2} \mathrm{O}_{2}$ and ascorbate oxidation was measured at $290 \mathrm{~nm}$ for $1 \mathrm{~min}$. Enzyme activity was measured using 
the molar extinction coefficient for ascorbate $\left(2.8 \mathrm{mM}^{-1} \mathrm{~cm}^{-1}\right)$ and the results expressed in $\mu \mathrm{Mol} \mathrm{H}_{2} \mathrm{O}_{2}$ min $^{-1} \mathrm{~g}^{-1} \mathrm{DM}$, taking into consideration that $2 \mathrm{~mol}$ ascorbate are required for a reduction of $1 \mathrm{~mol} \mathrm{H}_{2} \mathrm{O}_{2}$. Peroxidases were also detected by zymography. Samples of CgLP, PrLP and EtLP were separated by electrophoresis in $12.5 \%$ polyacrylamide gels in presence or absence of SDS. The gels were then immersed in 100 $\mathrm{mL}$ phosphate buffer $\mathrm{pH} 7.0$ containing $0.03 \% \mathrm{H}_{2} \mathrm{O}_{2}, 0.2 \%$ guaiacol and $0.03 \%$ 3-amino-9-etil-carbazole. Peroxidase isoforms were detected as brown bands (Johri et al., 2005).

Chitinolytic activity: Chitinase activity (E.C. 3.2.1.14) was determined by colorimetric assays and zymography. The colorimetric assays were performed using a modification of (Boller et al., 1983). The assay mixture contained $50 \mu \mathrm{L}$ of LP [1 mg mL ${ }^{-1}$ in $50 \mathrm{mM}$ sodium acetate buffer ( $\mathrm{pH} \mathrm{5.0)]} \mathrm{and}$ $2 \mathrm{mg}$ of colloidal chitin in a total volume of $500 \mu \mathrm{L}$. It was incubated at $37^{\circ} \mathrm{C}$ for $60 \mathrm{~min}$. The reaction was boiled for 5 $\mathrm{min}$ and then centrifuged $(10,000 \mathrm{~g}$ for $20 \mathrm{~min})$. For each 300 $\mu \mathrm{L}$ of the supernatant, $100 \mu \mathrm{L}$ of $0.6 \mathrm{M}$ potassium tetraborate were added and the amount of $\mathrm{N}$-acetyl-glucosamine liberated was determined according to (Reissig et al., 1955). The activity was estimated from a calibration curve using different concentrations of N-acetyl-glucosamine.

Chitinolytic activity was also detected in gels. The samples were separated by electrophoresis in $12.5 \%$ polyacrylamide gels containing $0.04 \%$ glycol-chitin at $8^{\circ} \mathrm{C}$. After electrophoresis, the gels were immersed in $2.5 \%$ of Triton X-100 and gentle shaken at $25^{\circ} \mathrm{C}$ for $30 \mathrm{~min}$ to eliminate SDS. After this stage, the gels were incubated at $37^{\circ} \mathrm{C}$ for $24 \mathrm{~h}$ in $50 \mathrm{mM}$ sodium acetate buffer ( $\mathrm{pH} \mathrm{5.0).} \mathrm{The} \mathrm{gels} \mathrm{were} \mathrm{then}$ incubated in $0.01 \%$ calcoflur MR 28 at $37^{\circ} \mathrm{C}$ for $1 \mathrm{~h}$. Chitinase isoforms were observed as cleared zones, by placing the gels on a UV transilluminator (UV ITF Labortechnik, Wasserburg, Germany).

Proteinase activities: Azocasein was used as a nonspecific substrate to investigate total proteolytic activity in CgLP, PrLP and EtLP. The reaction mixture contained $50 \mu \mathrm{L}$ (1 $\mathrm{mg} \mathrm{mL}^{-1}$ in acetate buffer $\mathrm{pH} 5.0$ ) of laticifer proteins (preincubated or not with $40 \mu \mathrm{L} 3 \mathrm{mM}$ DTT for $10 \mathrm{~min}$ ), $200 \mu \mathrm{L}$ of $1 \%$ azocasein in $50 \mathrm{mM}$ acetate buffer (pH 5.0), and 210 $\mu \mathrm{L}$ of acetate buffer (pH 5.0). The reaction was performed at $37^{\circ} \mathrm{C}$ and stopped 60 min later by adding $300 \mu \mathrm{L}$ of $20 \%$ trichloroacetic acid (TCA). The tubes were centrifuged $\left(10,000 \mathrm{~g}\right.$ for $10 \mathrm{~min}$ at $\left.25^{\circ} \mathrm{C}\right)$ and the supernatants (400 $\mu \mathrm{L}$ ) were alkalinized with $400 \mu \mathrm{L}$ of $2 \mathrm{~N} \mathrm{NaOH}$ solution. The color developed was measured by absorbance at $420 \mathrm{~nm}$ (Xavier-Filho et al., 1989). One unit of activity was defined as the amount of enzyme capable of increasing absorbance by $420 \mathrm{~nm}$ at 0.01 . Detection of proteinases by zymography was performed after protein separation in $12.5 \%$ polyacrylamide gels containing $0.1 \%$ gelatin at $4^{\circ} \mathrm{C}$ (Macedo et al., 2004). After electrophoresis, the gels were immersed in $2.5 \%$ of Triton X-100 (renaturing solution) and gently shaken for 30 min at $25^{\circ} \mathrm{C}$ to wash out SDS and allow protein reorganization. The gels were then incubated in $50 \mathrm{mM}$ acetate buffer $(\mathrm{pH}$ 5.0) containing $3 \mathrm{mM}$ DTT for $1 \mathrm{~h}$ at $37^{\circ} \mathrm{C}$. The incubated gels were stained with $0.2 \%$ Coomassie Brilliant Blue R-250 in $40 \%$ methanol and $10 \%$ acetic acid followed by treatment using the same solution without the dye. Enzymatic activity was detected as transparent bands in gels.

Assays for cysteine proteinases: Assays for cysteine proteinases were conducted utilizing BANA as a substrate. Aliquots of $50 \mu \mathrm{L}$ of CgLP or PrLP or EtLP [1 mg mL ${ }^{-1}$ in 50 $\mathrm{mM}$ phosphate buffer (pH 6.0)] were first incubated with 40 $\mu \mathrm{L}$ of an activation solution (3 mM DTT and $2 \mathrm{mM}$ EDTA) at $37^{\circ} \mathrm{C}$ for $10 \mathrm{~min}$ and $200 \mu \mathrm{L}$ of BANA were added [ $1 \mathrm{mM}$ in 50 mM phosphate buffer ( $\mathrm{pH} \mathrm{6.0)].} \mathrm{After} 30 \mathrm{~min}$, the reaction was stopped by adding $500 \mu \mathrm{L}$ of $2 \% \mathrm{HCl}$ in ethanol and $500 \mu \mathrm{L}$ of $0.06 \% 4$-(dimethyl-amino) cinnamaldehyde. After $40 \mathrm{~min}$, the resulting color was measured by absorbance at $540 \mathrm{~nm}$ (Abe et al., 1992). One unit of enzymatic activity was defined as the amount of enzyme that increased the absorbance at $540 \mathrm{~nm}$ by 0.01 .

Assays for serine proteinases: Assays for serine proteinases were performed using BApNA as a substrate. Aliquots of $50 \mu \mathrm{L}$ of CgLP or PrLP or EtLP [1 mg mL $\mathrm{m}^{-1}$ in 50 $\mathrm{mM}$ Tris- $\mathrm{HCl}(\mathrm{pH}$ 7.5)] were incubated with $250 \mu \mathrm{L} 50 \mathrm{mM}$ Tris- $\mathrm{HCl}(\mathrm{pH} 7.5)$ at $37^{\circ} \mathrm{C}$ for $10 \mathrm{~min}$ and $200 \mu \mathrm{L}$ of $1.25 \mathrm{mM}$ BApNA solution were added. After leaving the reaction at $37^{\circ} \mathrm{C}$ for $30 \mathrm{~min}$, it was then stopped by adding $150 \mu \mathrm{L}$ of $30 \%$ acetic acid. The resulting color was measured by absorbance at $405 \mathrm{~nm}$ (Gomes et al., 2005). All assays were performed in triplicate.

Heat stability and $\mathrm{pH}$ dependence of proteolytic activities: The effect of $\mathrm{pH}$ on enzyme effectiveness was evaluated using the following buffers/pH conditions: $50 \mathrm{mM}$ glycine (pH 2.6 and 10.0), $50 \mathrm{mM}$ sodium acetate (pH 4.0 and 5.0), $50 \mathrm{mM}$ sodium phosphate (pH 6.0 and 7.0) and 50 
$\mathrm{mM}$ Tris- $\mathrm{HCl}(\mathrm{pH} 8.0$ and 9.0). The remaining activities were determined at $37^{\circ} \mathrm{C}$ and the substrates azocasein, BANA and BApNA were tested as described above.

To test heat stability, CgLP and PrLP were incubated at different temperatures ranging from 37 to $90^{\circ} \mathrm{C}$ in $50 \mathrm{mM}$ acetate buffer, pH 5.0 for 15 or 30 min. After these periods, the proteolytic activity was assayed at $37^{\circ} \mathrm{C}$ using azocasein or BANA under standard assay conditions.

Inhibitory assays: To elucidate the mechanistic nature of the proteolytic activity in CgLP and PrLP, a set of inhibitors for different types of proteinases was tested. Aliquots of $50 \mu \mathrm{L}$ ( $1 \mathrm{mg} \mathrm{mL}^{-1}$ in $50 \mathrm{mM}$ acetate buffer, $\mathrm{pH} 5.0$ ) of CgLP or PrLP were pre-incubated at $25^{\circ} \mathrm{C}$ for $30 \mathrm{~min}$ in the presence of 20 $\mu \mathrm{L}$ of the following inhibitors: $5 \mathrm{mM}$ PMSF, $0.18 \mathrm{mM}$ of E-64, $10 \mathrm{mM}$ EDTA and $10 \mathrm{mM}$ pepstatin, in separate aliquots. The remaining activities were determined at $37^{\circ} \mathrm{C}, \mathrm{pH} 5.0$ using BANA or azocasein as substrates.

\section{RESULTS}

Protein content and protein profile: The latices of $C$. grandiflora, P. rubra and E. tirucalli were collected in distilled water and further fractionated based on the solubility and molecular mass of their constituents. The major fraction that precipitated in water was named rubber. The complementary materials that remained soluble in water and were retained in the dialysis membrane were named laticifer proteins (LP). Water-soluble low molecular substances that were filtered by the dialysis membrane were not recovered and were not included in the estimation of the dry mass. Rubber and LP fractions were initially quantified on the basis of dry mass. As shown in (Table 1), the rubber corresponded to more than $80 \%$ of the dry mass of $C$. grandiflora and $P$. rubra, while the remaining water soluble fraction comprised the minor part. The LP fraction of $E$. tirucalli, however, largely overcame the mass of its rubber fraction. This occurred because the rubber fraction of $E$. tirucalli poorly precipitated over the dialysis period or under the conditions of centrifugation. This effect did not interfere with the further analysis. The content of soluble proteins in $C$. grandiflora and $P$. rubra latices was estimated to be approximately 260 and $330 \mu \mathrm{g} \mathrm{mL}^{-1}$ of the whole latices respectively. After dialysis and centrifugation, both the rubber and LP fractions were recovered from $E$. tirucalli latex. However, attempts to estimate the protein content of EtLP using the Bradford's method (1976) failed even in doses as high as $10 \mathrm{mg} \mathrm{mL}^{-1}$. Despite this limitation, EtLP was assayed for characterization similarly to CgLP and PrLP.

Table 1. Recoveries of rubber and proteins from the whole latex of $C$. grandiflora, P. rubra and E. tirucalli.

\begin{tabular}{|c|c|c|c|c|c|c|}
\hline \multirow{2}{*}{ Latex $^{\mathrm{a}}$} & \multicolumn{2}{|c|}{ Dry mass of rubber } & \multicolumn{2}{|c|}{ Dry mass of LP } & \multirow{2}{*}{$\begin{array}{l}\text { Total mass of } L P \text { in the } \\
\text { whole latex } \\
\left(\mathrm{mg} \mathrm{mL}^{-1}\right)\end{array}$} & \multirow{2}{*}{$\begin{array}{l}\text { Total soluble proteins in LP } \\
\qquad\left(\mathrm{mg} \mathrm{mL}^{-1}\right)^{\mathrm{b}}\end{array}$} \\
\hline & $\mathrm{mg}$ & $\%$ & $\mathrm{mg}$ & $\%$ & & \\
\hline C. grandiflora & $1987.7 \pm 86.4$ & $96.6 \pm 0.3$ & $72.2 \pm 9.8$ & $3.3 \pm 0.3$ & $3.6 \pm 0.2$ & $0.26 \pm 0.03$ \\
\hline P. rubra & $1239.6 \pm 45.6$ & $82.2 \pm 4.5$ & $268.8 \pm 17.1$ & $17.8 \pm 2.8$ & $13.4 \pm 3.4$ & $0.33 \pm 0.02$ \\
\hline E. tirucalli & $540 \pm 40.5$ & $19.6 \pm 3.1$ & $2220.1 \pm 150.5$ & $80.4 \pm 5.3$ & $111 \pm 7.4$ & ND \\
\hline
\end{tabular}

${ }^{a}$ Four independent samples of $20 \mathrm{~mL}$ of latex from C. grandiflora, P. rubra and $E$. tirucalli. Dry mass of lyophilized proteins (LP) was considered as the fraction free of rubber. ${ }^{b}$ Estimated by Bradford. ND=Not detected.

Two dimensional electrophoresis analysis and mass spectrometry measurements did not produce a reliable pattern of proteins of EtLP. However, a good picture of the overall protein profiles of both PrLP and CgLP are shown (Figure 1). PrLP and CgLP exhibited very distinct protein profiles, suggesting consistent differences among their laticifer contents. A total of 118 protein spots with molecular masses ranging between 117.4 and $12.2 \mathrm{kDa}$ were found in PrLP gel. All proteins presented $\mathrm{pl}<6.5$. Interestingly, PrLP exhibited two major proteins with relative molecular masses of nearly 
$26 \mathrm{kDa}$ that corresponded to $69 \%$ of all protein detected in the latex. These proteins differing in $\mathrm{pl}$ appeared as a single peak in the mass spectrum corresponding to 26,392.337 (Figure $1 \mathrm{~A})$. Proteins spots with similar mass or pl were absent in both electrophoresis and the mass spectrum of $\mathrm{CgLP}$.

Proteins of $\mathrm{CgLP}$ were widely distributed in pl values ranging from 3 to 10 and spots with molecular masses varying from 74.5 to $12.5 \mathrm{kDa}$ (146 spots) were seen. However, proteins with $\mathrm{pl}<5.0$ were more abundant (59\%). The mass spectrum of proteins from CgLP latex did not exactly match its 2-DE profile. A few numbers of peaks with molecular masses ranging from $12.2 \mathrm{kDa}$ to $6.6 \mathrm{kDa}$ were seen in the spectrum (Figure 1B). However, these masses agreed with the major low molecular weight spots detected in the acidic region of 2-DE gels.

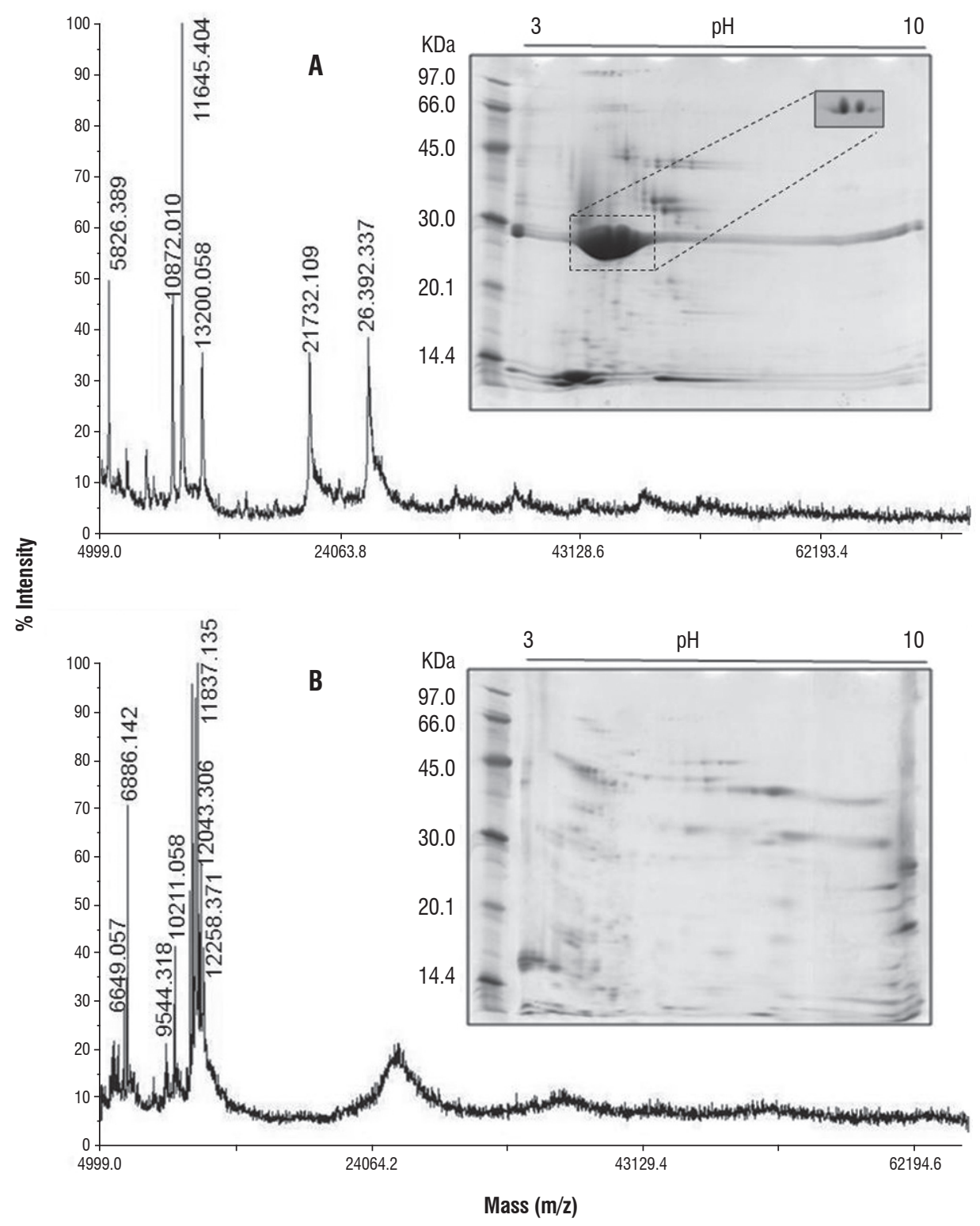

Figure 1. Masses spectra and two-dimensional polyacrylamide gel electrophoresis of soluble laticifer proteins from Plumeria rubra (A) and Cryptostegia grandiflora (B). Spectra were recorded after Matrix Assisted Laser Desorption Ionization (MALDI) and Time of Fly (TOF) analysis. Proteins (300 $\mu \mathrm{g})$ were fractionated in $12.5 \%$ polyacrylamide gels in the $\mathrm{pH}$ ranges of 3-10. 
Anti-oxidative activity of laticifers proteins: The activity of the anti-oxidantive enzymes investigated in $C$. grandiflora, $P$. rubra and $E$. tirucalli latices measured by colorimetric methods are presented in (Table 2). Ascorbate peroxidase activity was found in $C$. grandiflora and $P$. rubra latices but not detected in E. tirucalli even at doses as high as $10 \mathrm{mg} \mathrm{mL}^{-1}$. The ascorbate peroxidase activity in CgLP was almost twice as much as that determined in P. rubra and three times higher than that previously measured in the latex of Calotropis procera, shown as reference. The activity of peroxidases of CgLP and PrLP was confirmed by zymography (Figure 2). Samples were first submitted to electrophoresis with or without SDS. When denatured by SDS, CgLP and PrLP presented bands with peroxidase activity corresponding to proteins located in the upper region of the gels (Figure 2D). C. procera that was not previously investigated for peroxidases throughout zymography did not exhibit peroxidase activity in gels with SDS. However, under non denaturing conditions $C$. procera exhibited peroxidase activity while protein bands revealing peroxidase activity in CgLP and PrLP shifted in the gels compared to denaturing conditions. As seen in (Figure $2 \mathrm{E})$, isoforms of peroxidases are present in all latices. Peroxidase activity in E. tirucalli latex was not detected, confirming the colorimetric assays. Catalase activity was detected only in $C$. grandiflora latex and this result serves to highlight differences in the metabolism of laticifers (Table 2).

Table 2. Anti-oxidative activities of laticifer proteins studied.

\begin{tabular}{|c|c|c|c|}
\hline $\begin{array}{l}\text { Protein } \\
\text { samples }\end{array}$ & $\begin{array}{c}\text { APX Activity } \\
\left(\mu \mathrm{Mol} \mathrm{H}_{2} \mathrm{O2}\right. \\
\left.\mathrm{min}^{-1} \mathrm{~g}^{-1}\right)\end{array}$ & $\begin{array}{l}\text { SOD Activity } \\
\left(\mathrm{AU} \mathrm{g}^{-1}\right)\end{array}$ & $\begin{array}{l}\text { CAT Activity } \\
\left(\mu \mathrm{Mol} \mathrm{H}_{2} \mathrm{O}_{2}\right. \\
\left.\mathrm{min}^{-1} \mathrm{~g}^{-1}\right)\end{array}$ \\
\hline C. procera* & $0.117 \pm 0.05$ & $1007.74 \pm 91.89$ & $\mathrm{Nd}$ \\
\hline P. rubra & $0.196 \pm 0.01$ & $980.67 \pm 6.11$ & $\mathrm{Nd}$ \\
\hline $\begin{array}{c}\text { C. } \\
\text { grandiflora }\end{array}$ & $0.389 \pm 0.03$ & $886.36 \pm 0.35$ & $0.254 \pm 0.03$ \\
\hline E. tirucalli & ND & ND & ND \\
\hline
\end{tabular}

Values are mean \pm SD of triplicate points. APX, Ascorbate Peroxidase; SOD, Superoxide Dismutase; CAT, Catalase. $\mathrm{ND}=$ Not detected. ${ }^{\star} \mathrm{C}$. procera was used as reference (Freitas et al., 2007).

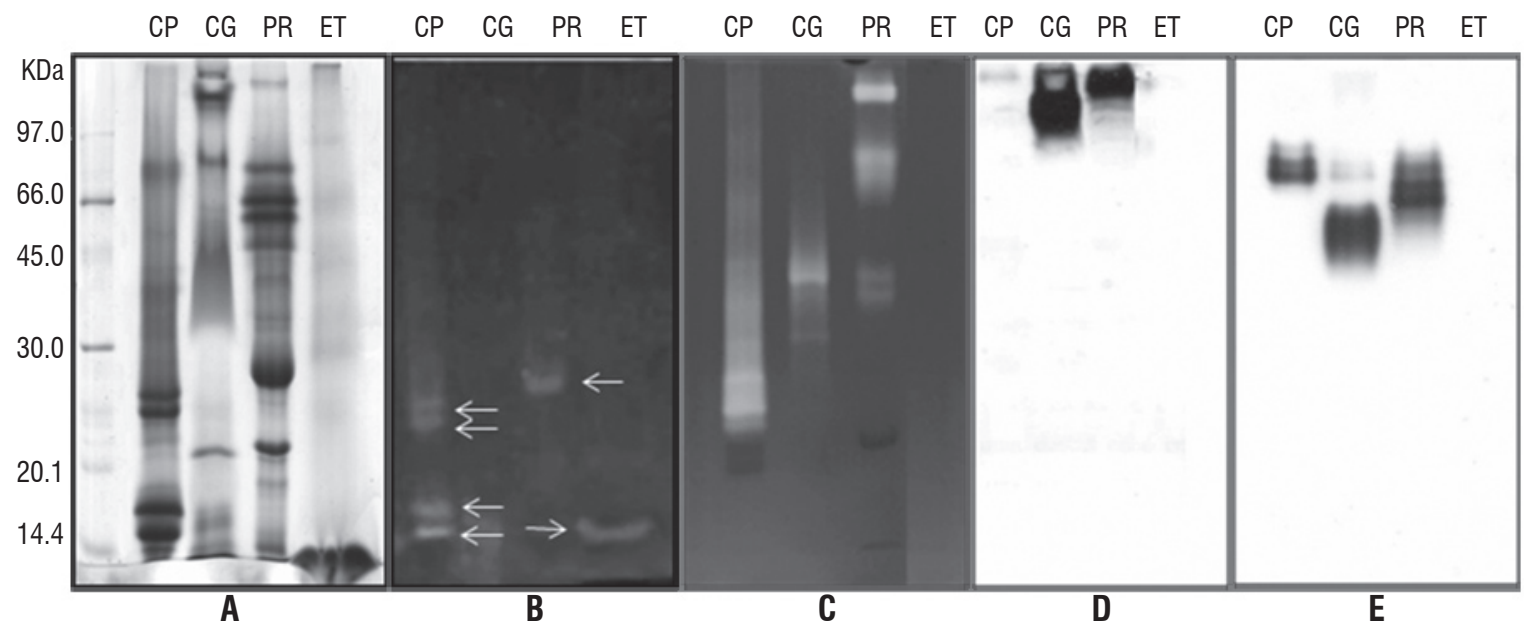

Figure 2. Detection of Chitinase (B), Proteinase (C) and Peroxidase activities (D and E) in gel. The samples were dissolved in Tris- $\mathrm{HCl} 0.0625 \mathrm{M}$ pH 6.8 in the presence of $1 \%$ SDS. (A) Control gel (12.5\%) was stained with Coomassie Brilhante Blue R-250. (E) Native zymogram to detection of Peroxidase activities in the absence of $1 \%$ SDS. CP: C. procera; CG: C. grandiflora; PR: P. rubra and ET: E. tirucalli.

Chitinase in the latices: Chitinolytic activity was measured in the latices using colloidal chitin as substrate at $\mathrm{pH}$ 5.0. The chitinolytic activity of the latex of $C$. procera was included as reference (Table 3 ). It is worth noting that chitinolytic activity was indubitably present in EtLP and represented the sole enzymatic activity found in this latex in this study. The latex of $P$. rubra presented an important chitinolitic activity. This activity was much higher than that determined in E. tirucalli (22-fold), C. grandiflora (43-fold) and C. procera latices (154-fold), respectively. The chitinolytic activity in the latices was also evident in the zymogram shown in (Figure 2B). However, the pattern of protein bands observed in the gel 
suggests differences in the structural features of the enzymes expressed in these fluids.

Table 3. Chitinase activity of laticifer proteins studied.

\begin{tabular}{cc}
\hline Protein samples & nKat $/ \mu \mathrm{gProtein}$ \\
\hline C. procera & $16.31 \pm 0.71$ \\
P. rubra & $2526.90 \pm 12.34$ \\
C. grandiflora & $58.68 \pm 4.45$ \\
E. tirucalli & $112.04 \pm 0,97$ \\
\hline
\end{tabular}

Values are mean $\pm S D$ of triplicate points. ${ }^{\star} C$. procera was used as reference (Freitas et al., 2007).

Proteinase activity in latices: Proteolytic activity has been recognized as the major endogenous enzyme activity in diverse latices. As shown in (Figure 2C), C. grandiflora and $P$. rubra exhibited proteolysis on gels soaked with gelatin, an ability previously described to $C$. procera. The proteolysis pattern was very distinct among the samples and suggested differences suitable to be investigated. EtLP did not exhibit proteolytic activity in any assay or experimental condition.

The maximum proteolysis of $\mathrm{CgLP}$ and PrLP was at $\mathrm{pH}$ 5.0 and 6.0, respectively, when azocasein sole or azocasein in presence of DTT were assayed. This activity was augmented in many orders of magnitude when BANA, a specific substrate for cysteine proteinases, was tested in the presence of DTT. However, proteolytic activity was only residual if BapNa, a specific substrate of serine proteinases, was assayed instead of BANA (Figure 3A and 4A). It is important to observe that the total proteolytic activity of CgLP was extraordinarily superior to that of PrLP. The proteolytic activity of CgLP resisted heat treatment and remained almost complete even when submitted to $60^{\circ} \mathrm{C}$ for $30 \mathrm{~min}$ (Figure 3B). Similar results were found when BANA was used (data not shown). The proteolytic activity of PrLP underwent an important decline after suffering similar treatment (Figure 4B).

To elucidate the mechanistic nature of the proteolytic activities, a set of inhibitory studies using specific inhibitors of proteinases was performed. Proteolytic activity of CgLP was not detected after incubation for 30 min with $0.18 \mathrm{mM} \mathrm{E}-64$, an irreversible inhibitor of cysteine proteinases belonging to the papain family (Figure $3 \mathrm{C}$ ). This result and that showing increased proteolysis after activation of CgLP with DTT (Figure 3A) suggest that cysteine proteinases occur in CgLP. The inhibitors PMSF, EDTA and pepstatin had no effect on the proteolytic activity of CgLP (Figure $3 \mathrm{C}$ ). These results also suggested that the major proteinases present in the latex of $C$. grandiflora belong to the cysteine group.

The proteolytic activity in PrLP was partially lost after incubation with E-64 (70\% inhibition) and with PMSF (30\% inhibition). These results suggest the presence of both, cysteine and serine proteinases in $P$. rubra latex (Figure 4C). Lack of inhibition by EDTA and pepstatin confirms the absence of metaloproteinases and aspartic proteinases, respectively in both latices (Figure $3 \mathrm{C}$ and $4 \mathrm{C}$ ). Taken together, these assays highlight important differences in the protein profiles and enzymatic activities in the latices studied.
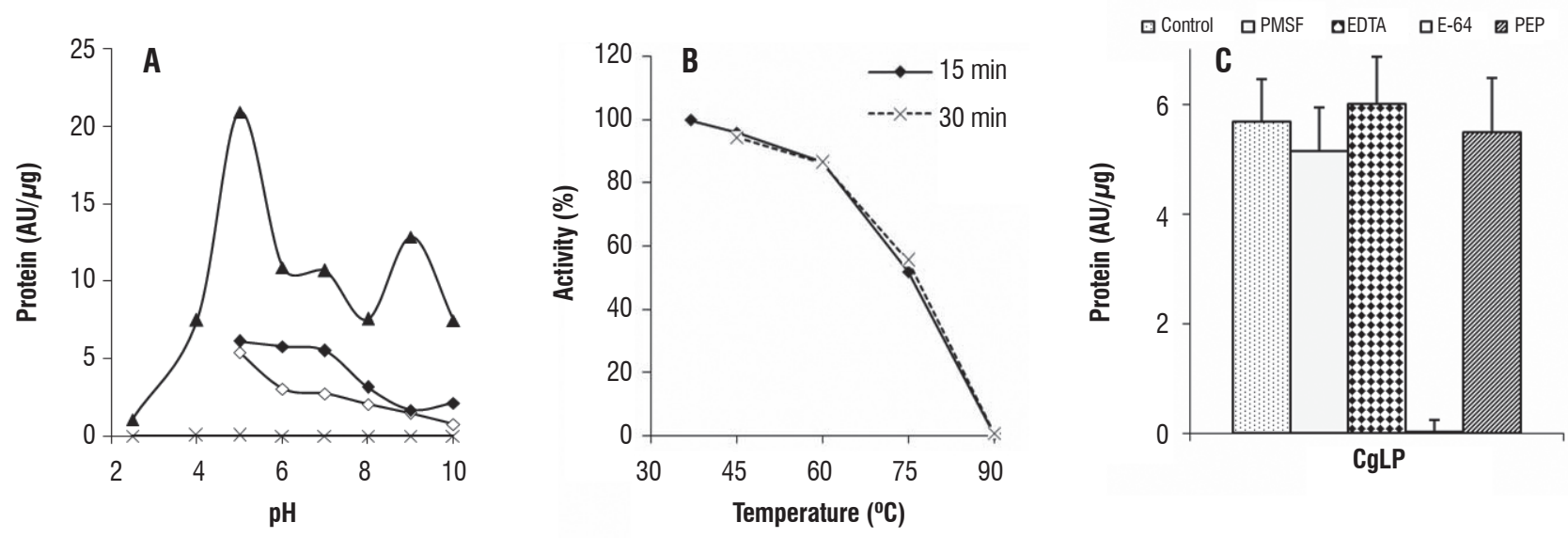

Figure 3. (A) Effect of pH on the proteolytic activity of laticifer proteins from C. grandiflora using Azocasein ( $\diamond)$, Azocasein in presence of DTT ( $\bullet$ ), BANA in presence of DTT $(\boldsymbol{\Lambda})$ and BapNa $(\times)$ as substrates. (B) Thermo-stability of the proteolytic activity at pH 5.0 using $1 \%$ azocasein in presence of DTT. (C) Effects of different enzyme inhibitors. Error bars indicate standard error of the mean. Each point has $n=3$. 

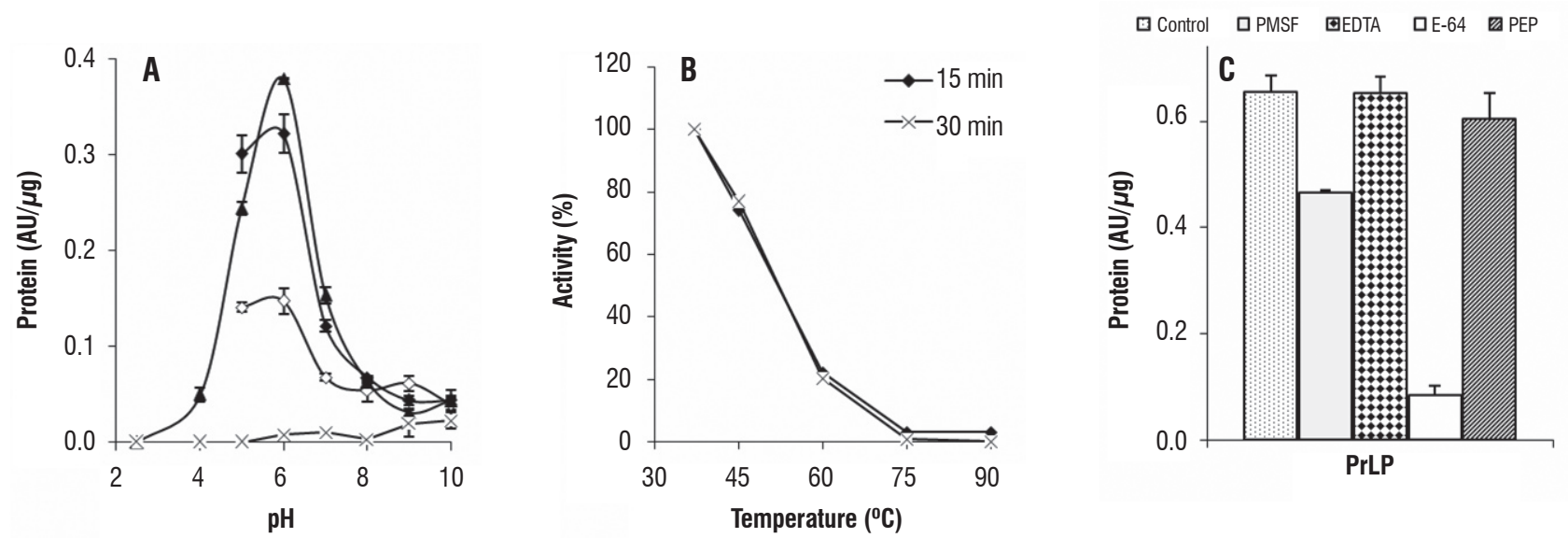

Figure 4. (A) Effect of $\mathrm{pH}$ on the proteolytic activity of laticifer proteins from $P$. rubra using Azocasein ( $\searrow$ ), Azocasein in presence of DTT ( $\bullet$ ), BANA in presence of DTT $(\boldsymbol{\Lambda})$ and BapNa $(\times)$ as substrates. (B) Thermo-stability of the proteolytic activity at pH 5.0 using $1 \%$ azocasein in presence of DTT. (C) Effects of different enzyme inhibitors. Error bars indicate standard error of the mean. Each point has $n=3$.

\section{DISCUSSION}

Apart from classical conducting systems widely spread in vascular plants whose basic functions in plant physiology are well defined, laticifer structures represent an independent secretory-like duct, whose intrinsic cellular metabolism and functions remain to be established in detail. Laticifers differentiate themselves from true conducting systems, not only in morphology but certainly in their functions. Laticifers are true specialized cells, which differentiate and express distinct DNA information leading to the synthesis of some specific proteins and metabolites. Natural rubber is the most common chemical product resulting from laticifer biochemistry. An increasing number of secondary metabolites have been studied in laticifers of different plants (Carter et al., 1997; Salunke et al., 2005). However, the lack of relevant information about proteins, other than those implicated in the primary cellular metabolism of latices, still limits more general elucidation of the role played by latices in plants. Therefore, in order to better understand the relevant functions of laticifers in plants, further studies of the proteins and enzymatic activities naturally occurring in these fluids are necessary. Following this line, we have recently determined some biochemical aspects of proteins present in the latex of C. procera and we have successfully correlated some of these activities with deleterious effects of latex proteins upon insect development (Freitas et al., 2007; Ramos et al., 2007).

Although only three latices were investigated here, it is clear that the protein content in laticifers of different species differs intensely. A general appreciation of the soluble proteins found in these fluids as observed by mass spectrometry and 2-DE analysis, suggests that very specific intrinsic activities take place in different latices. It is expected that enzymes involved in biosynthesis pathway of specific secondary metabolites account directly to these differences. It was interesting to note however, the absence of soluble proteins in E. tirucalli latex. The latex of Manilka zapota is another where proteins are scarce (Selvara et al., 1984). However, the laticifers of $C$. grandiflora and $P$. rubra exhibited an important number of protein spots seen in 2-DE. Complex protein profiles were also observed in the latices of $C$. procera, $H$. brasiliensis and Papaver somniferum (Posch et al., 1996; Decker et al., 2000; Freitas et al., 2007). In the latex of $H$. brasiliensis, approximately 200 distinct protein spots were found in 2-DE and more than 300 in the latex of $P$. somniferum. In the light of these results, laticifer cells are important sources of unknown proteins certainly of biological relevance. It should be mentioned here that both protein fraction from PrLP and $\mathrm{CgLP}$ exhibited the same 2-DE protein profile even when 
latices were collected with or without proteinase inhibitor (IAA and PMSF). This result suggests a low rate of endogenous proteolysis during latex processing.

Anti-oxidative activities are expected to occur in laticifers, even taking into account the endogenous oxidative process involving secondary metabolites in plants and within these specialized cells. However, anti-oxidative enzymes such as peroxidases, catalase and superoxide dismutase are recognized as pathogenesis-related proteins, whose activities are up or down regulated upon infection (van Loon et al., 2006). It has also been reported that synthesis de novo of these enzymes occurs after initiating infection (Svalheim et al., 2006). In this work we report abundant anti-oxidative activity in the laticifers of $C$. grandiflora and $P$. rubra, but marginal activity in $E$. tirucalli. The anti-oxidative metabolism holds different catalytic activities forming a network of enzymatic process that culminates with the destruction of reactive oxygen species (Mittler, 2002). As a whole these activities are commonly present in leaves that are the major tissue damaged upon infection. Laticifers of $C$. grandiflora and $P$. rubra as well as in $C$. procera are distributed in their leaves, and latex exudates upon injury. It is thus reasonable to suggest that these enzymatic activities play an important defensive role in plants under infectious process. It should be noted here that plants of $C$. grandiflora are perennial exhibiting healthy leaves even during the dry season. Finally, the involvement of anti-oxidative metabolism on defensive strategies against fungi has already been proposed (Caruso et al., 2001). In conclusion, the results show that latices exhibit enzymatic means to protect themselves against reactive oxygen species in vivo and this network might play an important defensive role against infection.

Chitinases are plant enzymes for which substrate [ $\beta-1,4-$ ( $N$-acetylglucosamine) $n]$ is not endogenously synthesized. This polysaccharide is a fundamental structural constituent of hyphae of many phytopathogenic fungi. Chitinases are abundant in leaves that are particularly susceptible to fungi attack (Rakwal et al., 2004). Chitinase was the sole enzymatic activity detected in laticifers of E. tirucalli among those investigated. This activity was almost double that found in C. grandiflora and seven times greater than measured in $C$. procera. E. tirucalli grows as a bush frequently with trunks which branch forming long and succulent smaller branches without clear foliar structure. The younger branches are long, green and cylindrical. Its laticifers are found along with the entire green body. The high level of chitinase activity detected in these laticifers, combined with the occurrence of highly toxic secondary metabolites already described in the literature may explain how E. tirucalli plants are protected against predators and infectious organisms. Despite exhibiting the lowest chitinase activity (Table 3 ) $C$. procera seems to possess different isoforms for this enzyme (Figure 2B). Such evidence was seen in our previous work (Ramos et al., 2007). We have made a special effort to determine the involvement of chitinases of $C$. procera on detrimental effects against insects but, only preliminary results have been obtained (Ramos et al., 2007). Additional assays are required before we can achieve a clearer picture for this question. As there is no data for $C$. grandiflora and $P$. rubra precludes further prospects.

With the exception of the synthesis of natural rubber, endogenous proteolytic activity is the most common and frequent activity investigated of the metabolism of laticifers. Proteolytic enzymes are recognized as playing a crucial role in a number of relevant events in plant life-cycle. This includes leaf senescence, breakdown of stored proteins during germination of seeds, development and ripening of fruits, regulatory mechanisms and programmed cell death (Domsalla and Melzing, 2008; Chowdhury et al., 2008). All of these events are part of the ordinary quotidian of health plants. Synthesis and accumulation of proteinases in highly specialized cells such as laticifers are intriguing. Endoproteinases are now recognized as pathogenesis-related proteins (van Loon et al., 2006). The defensive role of proteolytic enzymes in plat defense was revised by van der Hoorn and Jones (2004). Konno and collaborators (2004) described by direct experimental evidence the protective activity of papain, a proteinase from Carica papaya latex, against herbivorous.

Proteolytic activity was detected in $C$. grandiflora and $P$. rubra and both latices exhibited different patterns of digestion upon gelatin gels contrasting with that of $C$. procera, used as a reference. Cysteine proteinase activity accounted for almost all proteolytic activity of $C$. grandiflora while for $P$. rubra, serine proteinase activity was also estimated. Cysteine proteinases seem to predominate in the majority of laticifers studied. Although a defensive role for proteinases in latices can be ruled out, experimental studies are still very limited. $C$. grandiflora and $P$. rubra were not investigated in this regard. Currently we are trying to prove that the proteolytic activities 
of these latices participate in the defensive action against insects and phytopathogens, and these studies will appear elsewhere.

This study aimed at investigating the overall protein profiles of three latices and to partially characterize their endogenous enzyme activities, which are thought to participate in the defensive strategies in plants. It was concluded that the latices of $C$. grandiflora and $P$. rubra possess relevant enzymatic activities encompassing pathogenic related proteins. This reinforces the theory that laticifer cells of both plants are directly involved in plant protection. However, this hypothesis still requires experimental investigation. The latex of $E$. tirucalli is poor in protein activity. However, consistent data available in literature describe this latex as an important source of highly toxic secondary metabolites. This characteristic once more reminds us how distinct latices can be and merit continuous investigation to get new insights on this highly specialized plant tissue.

Acknowledgements: Biochemical, function and applied studies of laticifer fluids are supported by grants from Conselho Nacional de Desenvolvimento Científico e Tecnológico (CNPq); Coordenação de Aperfeiçoamento de Pessoal de Nível Superior (CAPES), Fundação Cearense de Apoio ao Desenvolvimento Científico e Tecnológico; Rede Nordeste de Biotecnologia (RENORBI0) and International Foundation for Science (IFS) Grant N. 3070-3.

\section{REFERENCES}

Abe M, Abe K, Kuroda M, Arai S (1992) Corn kernel cysteine proteinase inhibitor as a novel cystatin superfamily member of plant origin. Molecular cloning and expression studies. Eur. J. Biochem. 209:933-937.

Beers RF, Sizer IW (1952) A spectrophotometric method for measuring the breakdown of hydrogen peroxide by catalase. J. Biol. Chem.195:133-140.

Boller T, Gehri A, Mauch F, Vogeli U (1983) Chitinase in bean leaves: induction by ethylene, purification, properties and possible function. Plants 157:22-31.

Bradford MM (1976) A rapid and sensitive method for the quantification of microgram quantities of protein utilizing the principle of protein-dye binding. Anal. Biochem. 72:248-254.

Carter CA, Fomey RW, Gray EA, Gehring AM, Schneider TL, Young DB, Lovett CM, Scott L, Messer AC, Richardson DP (1997) Toxicarioside A. A new cardenolide isolated from Antiaris toxicaria latex-derived dart poison. Assignment of the $1 \mathrm{H}$ - and 13C-NMR shifts for an antiarigenin aglycone. Tetrahedron 53:13557-13566.

Caruso C, Chilosi G, Leonardi L, Bertini L, Magro P, Buonocore V, Caporale C (2001) A basic peroxidase from wheat kernel with antifungal activity. Phytochemistry 58:743-750.

Chowdhury I, Tharakan B, Bhat GK (2008) Caspases - An update. Comp. Biochem. Physiol. B 151:10-27.
Cornish K (2001) Similarities and differences in rubber biochemistry among plant species. Phytochemistry 57:1123-1134.

Decker G, Wanner G, Zenk MH, Lottspeich F (2000) Characterization of proteins in latex of the opium poppy (Papaver somniferum) using two-dimensional gel electroforesis and microsequencing. Electroforesis 21:3500-3516.

Domsalla A, Melzing MF (2008) Occurrence and properties of proteases in plant latices. Planta Med. 74:699-711.

Elsasser B, Krohn K, Akhtar MN, Florke U, Kouam SF, Kuigoua MG, Ngadjui BT, Abegaz BM, Antus S, Kurtan T (2005) Revision of the absolute configuration of plumericin and isoplumericin from Plumeria rubra. Chem. Biod. 2: 99808.

Farias LR, Costa FT, Souza LA, Pelegrini PB, Grossi-de-Sá MF, Neto SM, Bloch C, Laumann RA, Noronha EF, Franco OL (2007) Isolation of a novel Carica papaya $\square$-amylase inhibitor with deleterious activity toward Callosobruchus maculatus. Pestic. Biochem. Physiol. 87:255-260.

Freitas CDT, Oliveira JS, Miranda MRA, Macedo NMR, Sales MP, Villas-Boas LA, Ramos MV (2007) Enzymatic activities and protein profile of latex from Calotropis procera. Plant Physiol. Biochem. 45:781-789.

Giannopolitis CN, Rieis SK (1977) Superoxides dismutases. I. Occurrences in higher plants. Plant Physiol. 59:309-314.

Gomes CEM, Barbosa AEAD, Macedo IIP, Pitanga JCM, Moura FT, Oliveira AS (2005) Effect of trypsin inhibitor from Crotalaria pallida seeds on Callosobruchus maculatus (cowpea weevil) and Ceratitis capitata (fruit fly). Plant Physiol. Biochem. 43:1095-1102.

Hagel JM, Yeung EC, Facchini PJ (2008) Got milk? The secret life of laticifers. Trends Plant Sci. 13:631-639.

Johri S, Jamwal U, Rasool S, Kumar A, Verma V, Qazi GN (2005) Purification and characterization of peroxidases from Withania somnifera (AGB 002) and their ability to oxidize IAA. Plant Sci. 169:1014-1021.

Kekwick RG (2001) Latex and Laticifers, Encyclopedia of Life Sciences, Nature Publishing Group.

Konno K, Hirayama C, Nakamura M, Tateishi K, Tamura Y, Hattori M, Kohno K (2004) Papain protects papaya trees from herbivorous insects: role of cysteine proteases in latex. Plant J. 37:370-378.

Laemmli UK (1970) Cleavage of structural proteins during the assembly of the bacteriophage T4. Nature 227:680-685.

Macedo ML, Freire MD, Parra A (2004) A Kunitz-type inhibitor of coleopteran proteases, isolated from Adenanthera pavonina L. seeds and its effect on Callosobruchus maculatus. J. Agric. Food Chem. 52:2533-2540.

Mazoir N, Benharref A, Bailén M, Reina M, Gonzalez-Coloma A (2008) Bioactive triterpene derivatives from latex of two Euphorbia species. Phytochemistry 69:1328-1338.

Mittler R (2002) Oxidative stress, antioxidants and stress tolerance. Trends Plant Sci. 7:405-410.

Nakano Y, Asada K (1981) Hydrogen peroxide is scavenged by ascorbatespecific peroxidases in spinach chloroplasts. Plant Cell Physiol. 22:867-880.

Pickard WF (2008) Laticifers and secretory ducts: two other tube systems in plants. New Phytologist 177:877-888.

Posch A, Chen Z, Wheeler C, Dunn MJ, Raulf-Heimsoth M, Baur X (1996) Characterization and identification of latex allergens by two-dimensional electrophoresis and protein microsequencing. J. Allergy Clin. Immunol. 99:385-395.

Rakwal R, Yang G, Komatsu S (2004) Chitinase induced by jasmonic acid methyl jasmonate, ethylene and protein phosphatase inhibitors in rice. Mol. Biol. Reports 31:113-119.

Ramos MV, Freitas CDT, Stanisçuaski F, Macedo LLP, Sales MP, Sousa DP, Carlini CR (2007) Performance of distinct crop pests reared on diets enriched with latex proteins from Calotropis procera: Role of laticifer proteins in plant defense. Plant Sci. 173:349-357. 
Reissig JL, Strominger JL, Leloir LF (1955) A modified colorimetric method for the estimation of N-acetylamino sugars. J. Biol. Chem. 217:959-966.

Salunke BK, Kotkar HM, Mendki PS, Upasani SM, Maheshwari VL (2005) Efficacy of flavonoids in controlling Callosobruchus chinensis (L.) (Coleoptera: Bruchidae), a post-harvest pest of grain legumes. Crop Prot. 24:888-893.

Selvara JY, Pal DK (1984) Changes in the chemical composition and enzyme activity of two sapodilla (Manilkara zapota) cultivars during development and ripening. J. Hortic. Sci. 59:275-281.

Svalheim 0, Robertsen B (2006) Induction of peroxidases in cucumber hypocotyls by wounding and fungal infection. Physiologia Plantarum 78:261267.

Taira T, Ohdomari A, Nakama N, Shimoji M, Ishihara M (2005) Characterization and antifungal activity of Gazyumaru (Ficus microcarpa) latex Chitinases: Both the chitin-binding and the antifungal activities of class I Chitinases are reinforced with increasing ionic strength. Biosci. Biotechnol. Biochem. 69:811-818.

Van der Hoorn RAL, Jones JDG (2004) The plant proteolytic machinery and its role in defence. Curr. Opin. Plant Biol. 7:400-407.

Van Loon LC, Rep M, Pieterse CMJ (2006) Significance of Inducible Defenserelated Proteins in Infected Plants. Annu. Rev. Phytopathol. 44:135-62.

Vasconcelos EAR, Nogueira FCS, Abreu EFM, Gonçalves EF, Souza PAS, Campos FAP (2005) Protein Extraction from Cowpea Tissues for 2-D Gel Electrophoresis and Ms Analysis. Chromatographia 62:447-450.

Xavier-Filho J, Campos F, Maria AP, Ary B, Silva CP, Carvalho MMM, Macedo MLR, Lemos FJA, Grant J (1989) Poor correlation between the levels of proteinase inhibitors found in seeds of different cultivars of cowpea Vigna unguiculata) and the resistance/susceptibility to predation by Callosobruchus maculatus. J. Agric. Food Chem. 37:1139-1143. 